\title{
Quality of life of mothers at the sixth week and sixth month post partum and type of infant feeding
}

\author{
José Matías Triviño-Juárez, MD, MPH (Physician) a,*, \\ Beatriz Nieto-Pereda, MD, MPH (Physician) ${ }^{\mathrm{a}}$, Dulce Romero-Ayuso, PhD (Professor) ${ }^{\mathrm{b}}$, \\ Begoña Arruti-Sevilla, CNM (Midwife) ${ }^{c}$, Beatriz Avilés-Gámez, CNM (Midwife) ${ }^{c}$, \\ Maria João Forjaz, PhD (Scientific Researcher) ${ }^{\mathrm{d}}$, \\ Cristina Oliver-Barrecheguren, MD (Physician) ${ }^{\mathrm{e}}$, Sonia Mellizo-Díaz, RN (Nurse) , $^{\mathrm{e}}$ \\ Consuelo Soto-Lucía, CNM (Midwife) ${ }^{\mathrm{e}}$, Rosa Plá-Mestre, MD, MPH (Physician)a

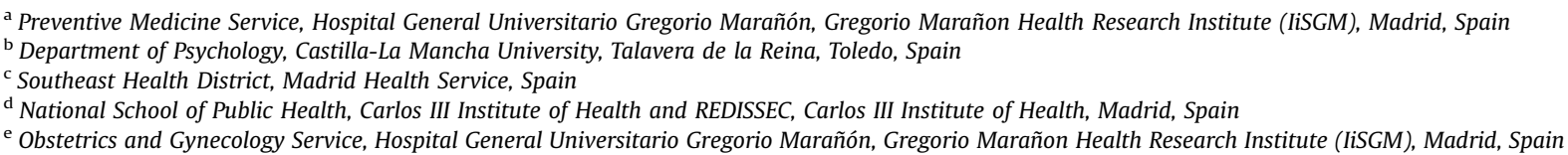

\section{A R T I C L E I N F O}

\section{Article history:}

Received 2 April 2015

Received in revised form

26 October 2015

Accepted 1 November 2015

Keywords:

Breast feeding

Quality of life

SF-36

Longitudinal study

\begin{abstract}
A B S T R A C T
Introduction: there is little scientific evidence on the relationship between maternal quality of life and type of infant feeding. The purpose of this study was to determine if there were differences in mother's quality of life by type of infant feeding.

Material and methods: longitudinal prospective study with 364 women who gave birth at a public hospital at Madrid, Spain, between February and October 2013. To be included, the participants had to be a healthy primigravida aged $18-45$ years who gave birth to a healthy newborn with a gestational age between 36 and 42 completed weeks, regardless of birth type. The hospital interviews were performed between 36 and 48 hours post partum in women who had case of vaginal/instrumental births and 60-72 hours post partum for women who had a caesarean birth. Telephone interviews were conducted at the sixth week and sixth month post partum, and included the SF-36 to measure quality of life. SF-36 scores were compared between breast feeding and artificial milk feeding. We also analysed the longitudinal change in SF-36 scores in both groups.

Results: at the sixth week post partum, regardless of the infant feeding modality, an increased mental health score was recorded for mothers who reported that their children ate and slept well and for those who did not go to the emergency hospital service because of concern over their baby's health. No significant differences in quality of life were found between the two groups at six months post partum. Between the sixth week and sixth month post partum, quality of life improved significantly in both groups.

Discussion: at the sixth week post partum, the proportion of children who ate and slept well and did not have to attend in an emergency hospital service was higher in the breast feeding group. This observation was associated with greater maternal quality of life. This positive indirect relationship between breast feeding and quality of life should be considered an additional maternal health benefit in the short term.
\end{abstract}

(c) 2015 Elsevier Ltd. All rights reserved.

\section{Introduction}

Breast feeding is the most natural and healthy form of infant feeding during the first years of life (Mortazavi et al., 2014a). The

\footnotetext{
* Correspondence to: Preventive Medicine Service, Hospital General Universitario Gregorio Marañón, Doctor Esquerdo, 46, 28007 Madrid, Spain.

E-mail address: josematias.trivino@salud.madrid.org (J.M. Triviño-Juárez).
}

benefits it provides for maternal and infant health in the short and long terms (Ladomenou et al., 2010; Tarrant et al., 2010) are maximised when the child is breast fed exclusively (Kramer and Kakuma, 2004). The World Health Organization (WHO) recommends exclusive breast feeding during the first six months of life and breast feeding complemented by appropriate foods until two years of age or older (WHO, 2003).

There is evidence that breast feeding promotes the bond between mother and child as well as the psychological well-being 
of children (Reynolds, 2001; Rao et al., 2002; Feldman and Eidelman, 2003; Chen et al., 2007). For many women, breast feeding is a significant element in the experience and expertise of motherhood (Schmied and Lupton, 2001; Zubaran and Foresti, 2011), and many mothers successfully breast feed their children despite difficulties in starting breast feeding (Mortazavi et al., 2014). For others, however, the breast feeding experience can be disruptive and unpleasant (Schmied and Barclay, 1999; Schmied and Lupton, 2001) and coping with associated problems, such as perception of insufficient milk supply, nipple and/or breast pain, difficulty combining childcare and housework with breast feeding in the early post partum weeks, may be difficult from both a physical and an emotional standpoint (Schmied and Barclay, 1999; Mortazavi et al., 2014a).

Other factors that influence how mothers experience breast feeding include the baby's health, relationships with family, socioeconomic status, and living conditions (Zubaran and Foresti, 2011) as well as employment status. In addition, during the post partum and breast feeding periods, mothers tend to experience significant changes in their physical and emotional health that may interfere with the continuity of breast feeding (Zubaran and Foresti, 2011).

Health-related quality of life is a broad concept that includes both physical and mental aspects (Schwartzmann, 2003). It is a construct based on the degree of satisfaction of a person with his or her physical condition, emotional state, and family and social life and on the meaning the individual attributes to his or her life (Schwartzmann, 2003). While there is a large body of literature on quality of life in the postpartum period (Jansen et al., 2007; Torkan et al., 2009; Mogos et al., 2013), there is little scientific evidence on possible changes in quality of life experienced by mothers during infant feeding. However, there are many factors that can interfere with quality of life and the experience of breast feeding, including sociodemographic, health and cultural (Kelly et al., 2006; Chen et al., 2007, 2011; Zubaran and Foresti, 2011; Mortazavi et al., 2014a).

In Spain, women are followed by a gynecologist, midwife or primary care physician during pregnancy, having at least three monitoring visits. The vast majority of women gives birth at public hospitals or private clinics, and most deliveries are medicalized. The rate of caesarean sections and episiotomy was $26.3 \%$ and $43 \%$, respectively, in 2010 (EURO-PERISTAT, 2013). For vaginal/instrumental births and caesarean births, if the mother and infant are healthy, they usually stay at the hospital for 48 hours after birth (72 hours after a caesarian section). The mother receives a scheduled review, performed by the primary care midwife between seven-ten days post partum. There is also a scheduled review of the newborn, conducted by the primary care paediatrician, within the first week of life, followed by monthly reviews. Maternity payed leave for working mothers is 16 weeks for women with non-multiple births (Castro-García and Pazos-Morán, 2007). After this time, working mothers have several options: some extend their maternity leave with unpaid leave, whereas others return to work full- or part-time. The care of the infant when the mother is working is provided at a daycare centre or at home by a housemaid or grandparents. These cultural aspects should be taken into account when studying the mother's quality of life in relation to infant feeding options.

In 2013, in Spain, the average age of mothers who gave the first birth was 30.42 years old (INE, 2013b). The 2011-2012 National Health Survey reported that the proportion of children who were fed exclusively with breast milk at six weeks was 66.19\% (INE, 2013a). The 2012 Annual Report of the National Health System presented that the proportion of children fed at six months with breast milk exclusively and in combination with artificial milk or other foods was 47\% (Ministerio de Sanidad, 2012). At the 6th week post partum (and also the 6th month), the proportion of children who were fed exclusively with breast milk, breast milk in combination with infant artificial milk and exclusively with infant artificial milk was similar in the different socio-economic levels (INE, 2013a).

Therefore, we explored differences in quality of life between the sixth week and sixth month post partum in mothers who chose different types of feeding. We also studied the quality of life of each group between the sixth week and sixth month post partum using a longitudinal approach. To our knowledge, this is the first longitudinal study on the relationship between quality of life and type of infant feeding.

\section{Material and methods}

\section{Design}

We performed an observational, longitudinal, prospective study.

\section{Participants}

The participants were women who gave birth at Gregorio Marañon Maternity Hospital, a public hospital in Madrid, Spain. This hospital is in accreditation process by the Initiative for the Humanizing of Assistance for Birth and Breastfeeding (IHAN), part of the international project 'Baby Friendly Hospital Initiation', promoted by WHO and UNICEF (WHO \& UNICEF, 2009).

The recruitment was performed between February and October 2013, and the number of women that fulfilled the inclusion criteria was 378 . They were invited to participate in the study, but 14 refused. So, the initial study sample was comprised of 364 women.

The selection was made using non-probability convenience sampling. To be included, the women had to be a healthy primigravida aged 18-45 years who gave birth to a healthy newborn with a gestational age between 36 and 42 completed weeks, regardless of the type of birth. The screening of healthy mothers and newborns, for their recruitment, was based on the hospital interview (we asked about medical, surgical, psychiatric and psychological history and use of medication) and review of their hospital records. In addition, women had to be able to speak Spanish. Women who had given birth to a healthy newborn but whose child was subsequently admitted to the neonatology unit were excluded.

\section{Comparison groups}

Considering the WHO criteria for infant feeding practices (WHO, 2008), we defined two study groups at six weeks and six months: at the sixth week, the breast feeding group consisted of mothers who were breast feeding exclusively and mothers who combined breast feeding with one or more intakes of artificial milk feeding; the artificial milk feeding group consisted of mothers who fed their children exclusively with infant artificial milk. At the sixth month, these criteria were maintained with the possibility, in one group or the other, of including liquid food or semi-liquid foods other than breast feeding and infant artificial milk.

\section{Data collection and instruments}

The recruitment of women and the administration of the hospital interviews were conducted by two doctors, a midwife and a hospital nurse, at Gregorio Marañon Maternity Hospital. The hospital interview was performed between 36 and 48 hours post partum in case of vaginal/instrumental deliveries and 60 and 72 
hours post partum for caesarean, in their usual hospital room, respecting their privacy and in the strictest confidentiality. Telephone interviews of the sixth week and sixth month were performed indistinctly by a doctor and a hospital nurse. All of them were trained by conducting simulated interviews and phone calls. We performed a pilot study of the hospital interview and telephone interviews of the sixth week and sixth month, with women recruited during the first two weeks of the study. These women were included in the total sample for analysis, because after the pilot study no changes in the design of the questionnaires were required.

During hospitalisation, we obtained demographic data (age, nationality, employment status before childbearing, socioeconomic status, and living with a partner) and recorded the type of birth, the weight and sex of the newborn. We also asked the mothers if they had initiated breast feeding, without distinguishing in the question whether it was exclusive breast feeding or breast feeding in combination with artificial milk feeding.

To determine the socio-economic level, mainly derived from the occupation, we used the classification proposed by the Group on Social Determinants of the Spanish Society of Epidemiology from the National Classification of Occupations of 2011 (DomingoSalvany et al., 2013), which contains seven levels: Level I: Directors and managers of establishments $\geq 10$ employees and professionals with university degrees; Level II: Directors and managers of establishments with $<10$ employees and professionals with university degrees and other technical support professionals, athletes, and artists; Level III: Intermediate occupations (employees, administrative and professional staff who support the public administration and other services); Level IV: Self-employed; Level V: Supervisors and workers in skilled technical occupations; Level VI: Primary sector and skilled and semiskilled workers; Level VII: Unskilled workers.

Socio-economic level was based on the income and occupational class of each member of the household (mother and partner). 'Respect to the income, we asked for: which incomes are higher, the mother's or the partner's?' So, if the mother's income was higher, then the socio-economic level attributed to her was that corresponding to her occupation. If her partner's income and socioeconomical level were higher, then the socio-economic level attributed to the mother was that of the partner.

At the sixth week and sixth month post partum, we asked the mothers if the newborn ate well and slept well ('does the baby sleep well?', 'does the baby eat well? with a yes/no answer option) and type of infant feeding. Respondents were also asked if they went to the emergency services of primary health care or hospitals (publics or privates) for problems affecting the mother and/or child (regardless of the scheduled reviews of the mother or newborn). We asked whether or not they had formal and family support for childcare and housework, too. Furthermore, the 36-item general health Short-Form questionnaire (SF-36) and the Edinburgh Postnatal Depression Scale (EPDS) were administered.

To measure quality of life, we used the Spanish version of the SF-36 (Alonso et al., 1995). The SF-36 is a generic scale useful for assessment of quality of life in the general population and in specific subgroups, it has been widely validated in Spain and has shown good reproducibility and validity (Alonso et al., 1995; Vilagut et al., 2005). It is intended for people aged $\geq 14$ years and can be self-administered or administered by telephone interview (Ware et al., 1993; Vilagut et al., 2005). It consists of 36 items and covers eight dimensions: physical function; role physical; bodily pain; general health; vitality; social function; role emotional; and mental health. These eight dimensions are summarised in the physical component summary and mental component summary. Scores range from 0 to 100 , so that the higher the score, the better perceived quality of life.
For screening for depression post partum, we used the EPDS, a questionnaire designed and validated by Cox (Cox et al., 1987). It consists of 10 items with four options as answers which are scored from 0 to 3 , according to the increasing order of severity of symptoms and a score range of $0-30$. The validated Spanish version lets us to suspect post partum depression with values $\geq 11$ (Garcia-Esteve et al., 2003). While administration by telephone interview is not validated, the EPDS scale had acceptable internal consistency in our study, with a Cronbach $\alpha$ of 0.77 and 0.79 at six weeks and six months, respectively.

\section{Ethics}

All women gave their written informed consent to participate. The study was approved by the Clinical Research Ethics Committee of Hospital General Universitario Gregorio Marañon, Madrid, Spain.

\section{Statistical analysis}

Descriptive statistics were used for quantitative and qualitative variables. The $t$-test or $\chi^{2}$ test was used to detect differences in sociodemographic variables, clinical variables, and HRQOL between the breast feeding and artificial milk feeding groups.

In variables whose distribution differed between the groups, the interaction was studied to investigate differences in the relationship between the type of feeding and the SF-36. For those dimensions of the SF-36 in which a statistically significant difference between the groups was observed, we performed an analysis of covariance adjusted for maternal age, employment status before childbearing, socio-economic status, newborn sex, and mode of birth (Chen et al., 2007; Chuang et al., 2007; de Tychey et al., 2008; Bai et al., 2015). Variables whose distribution differed significantly between the groups were also included in the model.

A paired $t$-test was performed to investigate the longitudinal change in SF-36 scores between the sixth week and sixth month post partum of each group (breast feeding, artificial milk feeding). Moreover, the time-group interaction was analysed to determine whether the longitudinal change in SF-36 scores differed depending on the group. Statistical significance was set at $p<0.05$. The analysis was performed using SPSS version 22 and Epidat version 3.1 .

\section{Findings}

\section{Participants}

The number of participating women, recruited at the hospital, was 364. At sixth week post partum, 337 women answered the telephone interview (92.60\%). The sample that completed the follow-up of six months post partum comprised 308 women (84.62\% of the initial sample). From the sample of women that completed the follow-up, $76.30 \%(n=235)$ were Spanish, with a mean age of 32.05 (SD: 5.28) years. A total of 297 women (96.40\%) lived with a partner. Before childbearing, $74 \%(n=228)$ were actively employed. In terms of socio-economic level, the largest proportion of the sample was grouped into levels I (30.20\%), II (15.90\%), and III (24\%). Birth was vaginal in 52.90\% $(n=163)$, instrumental in $26 \%(n=80)$, and caesarean in $21.10 \%(n=65)$. The average birth weight was $3206 \mathrm{~g}$ (SD: 396.56), and $52.60 \%$ of children $(n=162)$ were male. At discharge, 99\% $(n=305)$ of women had started breast feeding. In the analysis of the differences between groups that completed and not the six month follow-up, we found a significantly higher proportion of women who lived with a partner in the group that completed the followup $(p<0.001)$. 
Table 1

Differences between breast feeding and artificial milk feeding at the sixth week post partum.

\begin{tabular}{|c|c|c|c|c|c|}
\hline \multirow[t]{2}{*}{ Age at childbearing (years) } & \multicolumn{2}{|c|}{$\begin{array}{l}\text { Breast feeding } \\
(266) \\
\text { Mean (SD) } \\
32.12(5.21)\end{array}$} & \multicolumn{2}{|c|}{$\begin{array}{l}\text { Artificial milk } \\
\text { feeding (42) } \\
\text { Mean (SD) } \\
31.55(5.75)\end{array}$} & \multirow{2}{*}{$\begin{array}{l}p \text {-Value } \\
\text { (t-test) } \\
0.510 \\
\left(\chi^{2} \text { test }\right)\end{array}$} \\
\hline & $\mathbf{n}$ & $\%$ & $\mathbf{n}$ & $\%$ & \\
\hline \multicolumn{6}{|l|}{ Mode of birth } \\
\hline Vaginal & 145 & 54.50 & 18 & 42.90 & 0.215 \\
\hline Instrumental & 65 & 24.40 & 15 & 35.70 & 0.174 \\
\hline Caesarean & 56 & 21.10 & 9 & 21.40 & 0.882 \\
\hline Newborn sex (male) & 139 & 52.30 & 23 & 54.80 & 0.762 \\
\hline Spanish nationality & 201 & 75.60 & 34 & 81.00 & 0.450 \\
\hline \multicolumn{6}{|l|}{$\begin{array}{l}\text { Employment status before } \\
\text { childbirth }\end{array}$} \\
\hline Active & 199 & 74.80 & 29 & 69.00 & 0.547 \\
\hline Unemployed with benefits & 27 & 10.20 & 5 & 11.90 & 0.940 \\
\hline $\begin{array}{l}\text { Unemployed without } \\
\text { benefits }\end{array}$ & 31 & 11.70 & 4 & 9.50 & 0.886 \\
\hline Student & 1 & 0.40 & 1 & 2.40 & 0.639 \\
\hline Homemaker & 8 & 3.00 & 3 & 7.10 & 0.371 \\
\hline Lives with a partner & 258 & 97.00 & 39 & 92.90 & 0.180 \\
\hline \multicolumn{6}{|l|}{ Socio-economic level } \\
\hline I & 84 & 31.60 & 9 & 21.40 & 0.245 \\
\hline II & 38 & 14.30 & 11 & 26.20 & 0.083 \\
\hline III & 66 & 24.80 & 8 & 19.00 & 0.536 \\
\hline IV & 6 & 2.30 & 2 & 4.80 & 0.669 \\
\hline $\mathrm{V}$ & 20 & 7.50 & 5 & 11.90 & 0.507 \\
\hline VI & 47 & 17.70 & 6 & 14.30 & 0.749 \\
\hline VII & 5 & 1.90 & 1 & 2.40 & 0.702 \\
\hline The baby sleeps well & 219 & 82.30 & 29 & 69.00 & 0.043 \\
\hline The baby eats well & 264 & 99.20 & 39 & 92.90 & 0.002 \\
\hline $\begin{array}{l}\text { Family support with childcare } \\
\text { and housework }\end{array}$ & 156 & 58.60 & 26 & 61.90 & 0.690 \\
\hline $\begin{array}{l}\text { Support hired for childcare } \\
\text { and housework }\end{array}$ & 42 & 15.80 & 9 & 21.40 & 0.361 \\
\hline $\begin{array}{l}\text { EPDS score positive for post } \\
\text { partum depression }\end{array}$ & 35 & 13.20 & 7 & 16.70 & 0.538 \\
\hline Health services & 17 & 6.40 & 3 & 7.10 & 0.859 \\
\hline \multicolumn{6}{|l|}{$\begin{array}{l}\text { Emergency primary health } \\
\text { care due to mother's } \\
\text { health }\end{array}$} \\
\hline $\begin{array}{l}\text { Emergency hospital service } \\
\text { due to mother's health }\end{array}$ & 31 & 11.70 & 6 & 14.30 & 0.639 \\
\hline $\begin{array}{l}\text { Emergency primary health } \\
\text { care due to baby's health }\end{array}$ & 34 & 12.80 & 2 & 4.80 & 0.131 \\
\hline $\begin{array}{l}\text { Emergency hospital service } \\
\text { due to baby's health }\end{array}$ & 55 & 21.10 & 16 & 38.10 & 0.016 \\
\hline
\end{tabular}

Socio-economic level: I: Directors and managers of establishments $\geq 10$ employees and professionals with university degrees; II: Directors and managers of establishments with $<10$ employees and professionals with university degrees and other technical support professionals, athletes, and artists; III: Intermediate occupations (employees, administrative and professional staff who support the public administration and other services); IV: Self-employed; V: Supervisors and workers in skilled technical occupations; VI: Primary sector and skilled and semiskilled workers; VII: Unskilled workers.; EPDS: Edinburgh Postnatal Depression Scale.

\section{Differences between the groups at 6th week}

At week six $57.80 \%(n=178)$ of mothers were exclusively breast feeding their children; $28.60 \%(n=88)$ did it in combination with artificial milk feeding; $13.60 \%(n=42)$ fed their children exclusively with artificial milk. In the artificial milk feeding group, a significantly higher number of children neither ate well $(p=0.043)$ nor slept well $(p=0.002)$, compared to the breast feeding group (that includes mothers who breast feed exclusively and mothers who breast fed in combination with artificial milk feeding) (Table 1). Furthermore, the number of mothers who had used an emergency hospital service (public or private) because of concern over the baby's health was higher in the artificial milk group
( $p=0.016)$, too. No significant differences were found between the groups in other sociodemographic or clinical variables.

Regarding the SF-36 score, the mental health dimension in the breast feeding group was statistically higher (3.22 points, indicating better quality of life) than in the artificial milk feeding group $(p=0.025)$. There were no significant differences between the groups in other SF-36 dimensions or summary component scores (Table 2).

In the multivariate model (Table 3), the difference in the mental health dimension score between the groups was no longer statistically significant after controlling for the adjusted variables $(p=0.738)$. However, the mental health dimension was 3.07 points lower for mothers who reported that their children did not sleep well $(p=0.011), 14.92$ points lower for those who reported that their children did not eat well $(p<0.001)$, and 2.78 points lower for those who went to the emergency hospital service because of concern over the baby's health $(p=0.015)$.

\section{Differences between the groups at 6th month}

At the sixth month, breast feeding was exclusive in $12 \%(n=37)$, in combination with artificial milk feeding in $25 \%(n=77)$, or in combination with liquid or semi-solid food in $21.50 \%(n=66)$. Artificial milk feeding was used exclusively in $26.60 \%(n=82)$ and combined artificial milk feeding with liquid or semi-solid food in $14.90 \%(n=46)$.

With regard to the sociodemographic and clinical differences at the sixth month between women in the breastfeeding group ( $n=180)$ and women in the artificial milk feeding group ( $n=128)$, women's age in the breastfeeding group was marginally higher than in the artificial milk feeding group $(p=0.027$ ) (Table 4$)$. More women in the artificial milk feeding group were actively employed at the sixth month $(p=0.004)$, and more women in the breast feeding group were unemployed $(p=0.019)$. More women in the breast feeding group lived with a partner $(p=0.033)$ and belonged to socio-economic level I $(p=0.011)$. In addition, in the breast feeding group, a higher proportion of children ate well $(p=0.001)$. No significant differences were found between the groups for the remaining variables.

No significant differences were found between the groups at six months in any of the dimensions of the SF-36 score or summary component scores (Table 2).

\section{Longitudinal change in SF-36 scores}

In the group of women who breast fed between the sixth week and sixth month $(n=180)$, a significant increase was observed in physical function (1.30 points; $p<0.001)$, role physical (3.80 points; $p<0.001$ ), bodily pain (3.90 points; $p<0.001$ ), social function ( 2.42 points; $p=0.003$ ), and mental health ( 2.40 points; $p<0.001)$ and in the physical health component score $(2.50$ points; $p<0.001)$ and mental health component score (1.25 points; $p=0.041$ ). In other words, an improvement was observed in the areas explored (Table 2, Figs. 1 and 2). In the group of women who maintained artificial milk feeding between the two study periods $(n=42)$, a significant increase was observed in the scores for the following dimensions: physical function (1.82 points; $p=0.005$ ), bodily pain (3.88 points; $p=0.039$ ), and mental health (5.42 points; $p=0.001$ ) (Table 2 ; Fig. 1 ). We also analysed the period of time by group relationship for each dimension (Table 2; Fig. 1) and the SF-36 components summary (Table 2; Fig. 2). This relationship was not significant in any case. 
Table 2

SF-36 scores.

\begin{tabular}{|c|c|c|c|c|c|c|c|c|c|}
\hline & \multicolumn{3}{|c|}{ Six weeks after childbirth } & \multicolumn{3}{|c|}{ Six months after childbirth } & \multicolumn{2}{|c|}{$\begin{array}{l}\text { Longitudinal intragroup } \\
\text { change* } p \text { value (paired } t \text { - }_{\text {test) }}\end{array}$} & \multirow{2}{*}{$\begin{array}{l}\text { Longitudinal inter- } \\
\text { group change } \\
\qquad p \text { Value }\end{array}$} \\
\hline & $\begin{array}{l}\text { Breast feed- } \\
\text { ing (180) } \\
\text { Average (SD) }\end{array}$ & $\begin{array}{l}\text { Artificial milk } \\
\text { feeding (42) } \\
\text { Average (SD) }\end{array}$ & $\begin{array}{l}p \text {-Value (stu- } \\
\text { dent } t \text {-test) }\end{array}$ & $\begin{array}{l}\text { Breast feed- } \\
\text { ing (180) } \\
\text { Average } \\
\text { (SD) }\end{array}$ & $\begin{array}{l}\text { Artificial milk } \\
\text { feeding (128) } \\
\text { Average (SD) }\end{array}$ & $\begin{array}{c}p \text {-Value (stu- } \\
\text { dent } t \text {-test) }\end{array}$ & $\begin{array}{l}\text { Breast feed- } \\
\text { ing (180) }\end{array}$ & $\begin{array}{l}\text { Artificial milk } \\
\text { feeding (42) }\end{array}$ & \\
\hline $\begin{array}{l}\text { Physical } \\
\text { functioning }\end{array}$ & $55.65(3.41)$ & $55.63(3.85)$ & 0.970 & $56.97(2.00)$ & $57.21(1.58)$ & 0.231 & $<0.001$ & 0.005 & 0.527 \\
\hline Role physical & $50.63(10.03)$ & $50.48(10.31)$ & 0.930 & $53.88(7.04)$ & $53.56(5.90)$ & 0.679 & $<0.001$ & 0.096 & 0.389 \\
\hline Bodily pain & $52.97(9.35)$ & $52.06(9.73)$ & 0.562 & $56.41(9.06)$ & $56.91(8.31)$ & 0.623 & $<0.001$ & 0.039 & 0.946 \\
\hline General health & $58.44(6.36)$ & $56.49(8.85)$ & 0.177 & $58.84(6.53)$ & 58.73 (5.89) & 0.876 & 0.203 & 0.155 & 0.667 \\
\hline Vitality & $52.05(8.03)$ & $49.70(9.90)$ & 0.149 & $52.96(7.64)$ & $52.27(6.97)$ & 0.420 & 0.262 & 0.051 & 0.279 \\
\hline Social functioning & $51.91(9.67)$ & $49.70(11.94)$ & 0.259 & $53.66(8.34)$ & $53.66(7.74)$ & 0.996 & 0.003 & 0.206 & 0.971 \\
\hline Role emotional & $51.78(9.02)$ & $50.73(9.79)$ & 0.495 & $52.80(7.94)$ & $52.03(8.10)$ & 0.407 & 0.175 & 0.300 & 0.777 \\
\hline Mental health & $52.09(8.20)$ & $48.87(10.62)$ & 0.025 & $55.00(7.06)$ & $53.91(7.08)$ & 0.186 & $<0.001$ & 0.001 & 0.097 \\
\hline $\begin{array}{l}\text { Physical component } \\
\text { summary }\end{array}$ & $54.93(6.01)$ & $54.87(7.12)$ & 0.955 & $56.97(5.22)$ & $57.46(4.82)$ & 0.403 & $<0.001$ & 0.148 & 0.502 \\
\hline $\begin{array}{l}\text { Mental component } \\
\text { summary }\end{array}$ & $50.99(8.02)$ & $47.75(11.22)$ & 0.081 & $52.48(7.81)$ & $51.39(7.47)$ & 0.221 & 0.041 & 0.050 & 0.205 \\
\hline
\end{tabular}

* Changes in SF-36 scores between the sixth week and sixth month post partum in the group of women who maintained the same type of feeding.

$\dagger$ Differences in the SF-36 between the sixth week and sixth month post partum in the group who maintained breast feeding and who maintained artificial milk feeding.

\section{Discussion}

It is generally accepted that breast feeding is beneficial for mothers and their children in the short and long terms (Chen et al., 2007; Bai et al., 2015; Mortazavi et al., 2014a). However, few data are available on the relationship between the type of infant feeding and maternal quality of life (Chen et al., 2007). The main purpose of our study was to determine whether there were differences in quality of life at the sixth week and sixth month post partum depending on the type of infant feeding and the evolution of quality of life of the mothers in each group. To our knowledge, this is the first longitudinal study to explore the relationship between quality of life and the type of infant feeding at two time points.

All but three women initiated breast feeding at the hospital discharge. Although the socio-economic position can influence this, several studies have shown that one of the most important factors to promote the choice and the beginning of breast feeding is the support by health professionals during hospitalisation (Estévez González et al., 2002; Baztan et al., 2009). Our hospital is in accreditation process by the Initiative for the Humanizing of Assistance for Birth and Breastfeeding (IHAN), part of the international project 'Baby Friendly Hospital Initiation', promoted by WHO and UNICEF (WHO \& UNICEF, 2009). Thanks to this strategy, our professionals are very conscious of promoting breast feeding. This could partly explain why only three women at discharge did not initiate breast feeding.

Although our telephone follow-up is not equivalent to puerperal monitoring by gynecologists and midwives, it is striking that our study had a higher proportion of women who lived with a partner in the group that completed the sixth month follow-up. There is literature that shows that the presence of the partner, not only in pregnancy and childbirth, but also in the postpartum period, supports monitoring of women in the postpartum period and strengthens their bond with their child (Manrique de Lara et al., 2007; Ramírez and Rodríguez, 2014). Therefore, professionals should consider identifying these situations to reduce the loss of puerperal monitoring of women who do not live with a partner.

At the sixth week post partum, women in the breast feeding group reported better mental health than those in the artificial milk feeding group, although this difference was no longer statistically significant after controlling for the other variables in the multivariate analysis. At the sixth month post partum, the two groups showed similar quality of life in all dimensions and components.

These results contrast with those obtained by Chen et al. (2007), whose cross-sectional study showed that mothers who breast fed for at least six months had higher quality of life in terms of general health and mental health than mothers who did not breast feed or who had done so for less time. Therefore, breast feeding had a positive effect on the mothers' quality of life. However, this positive effect on quality of life may be caused by factors which favour breast feeding and not breast feeding itself. Several studies show that less stressful childcare and life in general and more social and family support are associated with a longer duration of breast feeding, elements which by themselves are associated with higher quality of life (Isabella and Isabella, 1994; Boettcher et al., 1999; Flacking et al., 2006; Hegney et al., 2008; Kim, 2010). Regardless of the type of infant feeding, after controlling for the variables of adjustment, the score of the mental health dimension at the sixth week post partum was lower for mothers who attended the emergency hospital service because of concern over the baby's health, for those who reported that their children slept worse, and much lower for those who reported that their children ate worse. Indeed, these circumstances were less frequent at the sixth week post partum in the breast feeding group. The immunisation properties of breast feeding are well known, especially in the prevention of respiratory and gastrointestinal infections during the first months of life (Ibanez et al., 2012). It has also been suggested that the melatonin provided with nightly breast feeding plays a major role in improving sleep and reducing colic, as compared with children who are fed exclusively with artificial milk (Cubero et al., 2005; Cohen et al., 2012).

Considering these results, we believe that breast feeding itself does not have a positive direct effect on maternal quality of life, although it does have a positive indirect effect in that it protects children from infections, promotes sleep, reduces colic, and increases appetite, all of which are associated with better maternal mental health.

Six months post partum, more mothers were actively employed in the artificial milk feeding group. This could favour cessation of 
Table 3

Mental health according to SF-36 at the sixth week.

\begin{tabular}{|c|c|c|c|c|c|}
\hline & \multirow[t]{2}{*}{$\beta$} & \multirow[t]{2}{*}{$\begin{array}{l}\text { Standard } \\
\text { error }\end{array}$} & \multirow[t]{2}{*}{$p$ Value } & \multicolumn{2}{|c|}{$\begin{array}{l}\text { 95\% Confidence } \\
\text { interval }\end{array}$} \\
\hline & & & & $\begin{array}{l}\text { Lower } \\
\text { limit }\end{array}$ & $\begin{array}{l}\text { Upper } \\
\text { limit }\end{array}$ \\
\hline Intercept & 49.56 & 4.96 & $<0.001$ & 39.79 & 59.32 \\
\hline Breast feeding & 0.47 & 1.42 & 0.738 & -2.31 & 3.26 \\
\hline Newborn (male) & -0.63 & 0.97 & 0.513 & -2.54 & 1.27 \\
\hline \multicolumn{6}{|l|}{$\begin{array}{l}\text { Mode of birth (reference: } \\
\text { caesarean) }\end{array}$} \\
\hline Vaginal & 1.65 & 1.29 & 0.201 & -0.89 & 4.20 \\
\hline Instrumental & 1.34 & 1.45 & 0.357 & -1.52 & 4.20 \\
\hline $\begin{array}{l}\text { The baby does not sleep } \\
\text { well }\end{array}$ & -3.07 & 1.20 & 0.011 & -5.44 & -0.70 \\
\hline $\begin{array}{l}\text { The baby does not eat } \\
\text { well }\end{array}$ & -14.92 & 3.74 & $<0.001$ & -22.27 & -7.56 \\
\hline $\begin{array}{l}\text { Use of emergency medi- } \\
\text { cal service due to } \\
\text { baby's health }\end{array}$ & -2.78 & 1.14 & 0.015 & -5.03 & -0.53 \\
\hline \multicolumn{6}{|l|}{$\begin{array}{l}\text { Employment status } \\
\text { before childbirth } \\
\text { (reference: } \\
\text { homemaker) }\end{array}$} \\
\hline Active & 2.97 & 2.89 & 0.305 & -2.72 & .8 .67 \\
\hline $\begin{array}{l}\text { Unemployed with } \\
\text { benefits }\end{array}$ & 0.29 & 3.15 & 0.928 & -5.91 & 6.48 \\
\hline $\begin{array}{l}\text { Unemployed without } \\
\text { benefits }\end{array}$ & 0.49 & 3.03 & 0.872 & -5.48 & 6.45 \\
\hline Student & -11.93 & 6.37 & 0.062 & -24.47 & 0.61 \\
\hline \multicolumn{6}{|l|}{$\begin{array}{l}\text { Socio-economic level } \\
\text { (reference: level VII) }\end{array}$} \\
\hline I & 1.05 & 3.72 & 0.777 & -6.28 & 8.38 \\
\hline II & -2.43 & 3.82 & 0.526 & -9.95 & 5.10 \\
\hline III & -0.70 & 3.73 & 0.851 & -8.05 & 6.65 \\
\hline IV & -2.58 & 4.52 & 0.569 & -11.84 & 6.32 \\
\hline V & 1.72 & 3.92 & 0.661 & -9.44 & 6.00 \\
\hline VI & -0.13 & 3.72 & 0.971 & -7.47 & 7.20 \\
\hline Age at childbearing & -0.07 & 0.12 & 0.550 & -0.30 & 0.16 \\
\hline
\end{tabular}

Socio-economic level: I: Directors and managers of establishments $\geq 10$ employees and professionals with university degrees; II: Directors and managers of establishments with $<10$ employees and professionals with university degrees and other technical support professionals, athletes, and artists; III: Intermediate occupations (employees, administrative and professional staff who support the public administration and other services); IV: Self-employed; V: Supervisors and workers in skilled technical occupations; VI: Primary sector and skilled and semiskilled workers; VII: Unskilled workers.

breast feeding. Similar findings have been reported elsewhere, indicating that employment is one of the main obstacles when it comes to continuing breast feeding (Johnston and Esposito, 2007; Thulier and Mercer, 2009; Skafida, 2012). Bai et al. (2015) reported that a later return to work and fewer working hours increase the duration of any form of breast feeding.

We observed an improvement in physical and mental health in both groups between the sixth week and sixth month post partum. Although the number of dimensions that improved was higher for the breast feeding group, it is noteworthy that there were no significant statistical differences between the groups in quality of life scores at six months post partum.

Some researchers have reported that the physical performance of women and their perceived level of health and wellness decrease during the pregnancy (Otchet et al., 1999; Haas et al., 2005). We found that the improvement in quality of life scores in both groups between the sixth week and sixth month post partum can be explained by the gradual recovery of pre-pregnancy status (Mortazavi et al., 2014b). Perhaps the most relevant indicator of the progress of quality of life is the improvement women experienced between the two time points.

Our study is subject to a series of limitations. First, our sample was obtained using non-probability convenience sampling. One
Table 4

Sociodemographic and clinical differences between groups of breast feeding and infant artificial milk at the sixth month post partum.

\begin{tabular}{|c|c|c|c|c|c|}
\hline \multirow{2}{*}{$\begin{array}{l}\text { Age at childbearing } \\
\text { (years) }\end{array}$} & \multicolumn{2}{|c|}{$\begin{array}{l}\text { Breast feeding } \\
(180) \\
\text { Average (SD) }\end{array}$} & \multicolumn{2}{|c|}{$\begin{array}{l}\text { Artificial milk } \\
\text { feeding(128) } \\
\text { Average (SD) }\end{array}$} & \multirow{2}{*}{$\begin{array}{l}p \text {-value } \\
\text { (Student } t \text { - } \\
\text { test) } \\
0.027 \\
\left(\chi^{2} \text { test }\right)\end{array}$} \\
\hline & $\mathrm{n}$ & $\%$ & $\mathrm{n}$ & $\%$ & \\
\hline \multicolumn{6}{|l|}{ Mode of birth } \\
\hline Vaginal & 91 & 50.60 & 72 & 56.30 & 0.389 \\
\hline Instrumental & 48 & 26.70 & 32 & 25.00 & 0.069 \\
\hline Caesarean & 41 & 22.80 & 24 & 18.80 & 0.476 \\
\hline Newborn sex (male) & 95 & 52.80 & 67 & 52.30 & 0.940 \\
\hline \multicolumn{6}{|l|}{$\begin{array}{l}\text { Employment status } \\
6 \text { months post partum }\end{array}$} \\
\hline Active & 92 & 51.40 & 87 & 68.50 & 0.004 \\
\hline $\begin{array}{l}\text { Unemployed with } \\
\text { benefits }\end{array}$ & 32 & 17.90 & 10 & 7.90 & 0.019 \\
\hline $\begin{array}{l}\text { Unemployed without } \\
\text { benefits }\end{array}$ & 25 & 14.00 & 13 & 10.20 & 0.420 \\
\hline Homemaker & 1 & 0.60 & 3 & 2.40 & 0.392 \\
\hline Maternity leave & 29 & 16.20 & 13 & 10.20 & 0.183 \\
\hline Lives with a partner & 177 & 98.30 & 120 & 93.80 & 0.033 \\
\hline \multicolumn{6}{|l|}{ Socio-economic level } \\
\hline I & 65 & 36.10 & 28 & 21.90 & 0.011 \\
\hline II & 25 & 13.90 & 24 & 18.80 & 0.322 \\
\hline III & 41 & 22.80 & 33 & 25.80 & 0.636 \\
\hline IV & 4 & 2.20 & 4 & 3.10 & 0.899 \\
\hline $\mathbf{V}$ & 10 & 5.60 & 15 & 11.70 & 0.082 \\
\hline VI & 32 & 17.80 & 21 & 16.40 & 0.872 \\
\hline VII & 3 & 1.70 & 3 & 2.30 & 0.996 \\
\hline The baby sleeps well & 147 & 81.70 & 112 & 87.50 & 0.168 \\
\hline The baby eats well & 172 & 95.60 & 108 & 84.40 & 0.001 \\
\hline $\begin{array}{l}\text { Family support with } \\
\text { childcare and } \\
\text { housework }\end{array}$ & 102) & 56.70 & 76 & 59.40 & 0.635 \\
\hline $\begin{array}{l}\text { Support hired for child- } \\
\text { care and housework }\end{array}$ & 17 & 9.50 & 19 & 14.80 & 0.151 \\
\hline $\begin{array}{l}\text { EPDS score positive for } \\
\text { post partum depression }\end{array}$ & 11 & 6.10 & 3 & 2.30 & 0.118 \\
\hline Health services & 1 & 0.60 & 2 & 1.60 & 0.375 \\
\hline \multicolumn{6}{|c|}{$\begin{array}{l}\text { Use of emergency pri- } \\
\text { mary health care due } \\
\text { to mother's health }\end{array}$} \\
\hline $\begin{array}{l}\text { Use of emergency medical } \\
\text { service due to mother's } \\
\text { health }\end{array}$ & 11 & 6.20 & 3 & 2.40 & 0.114 \\
\hline $\begin{array}{l}\text { Use of emergency primary } \\
\text { health care due to } \\
\text { baby's health }\end{array}$ & 7 & 3.90 & 5 & 3.90 & 0.994 \\
\hline $\begin{array}{l}\text { Use of emergency medical } \\
\text { service due to baby's } \\
\text { health }\end{array}$ & 44 & 24.70 & 32 & 25.20 & 0.924 \\
\hline
\end{tabular}

Socio-economic level: I: Directors and managers of establishments $\geq 10$ employees and professionals with university degrees; II: Directors and managers of establishments with $<10$ employees and professionals with university degrees and other technical support professionals, athletes, and artists; III: Intermediate occupations (employees, administrative and professional staff who support the public administration and other services); IV: Self-employed; V: Supervisors and workers in skilled technical occupations; VI: Primary sector and skilled and semiskilled workers; VII: Unskilled workers; EPDS: Edinburgh Postnatal Depression Scale.

limitation of this type of sampling is the difficult to generalise the results to the population, although is fully useful for exploratory studies, like ours (Hernández et al., 2010). Generalisation to the population is also limited by the smaller sample size of the group with artificial milk feeding at the sixth week. Second, our sample consisted of healthy primigravidae with healthy newborns who had not been admitted to the neonatology service. Consequently, our findings could differ from those of multigravidas with an underlying disease or children with significant health problems. 

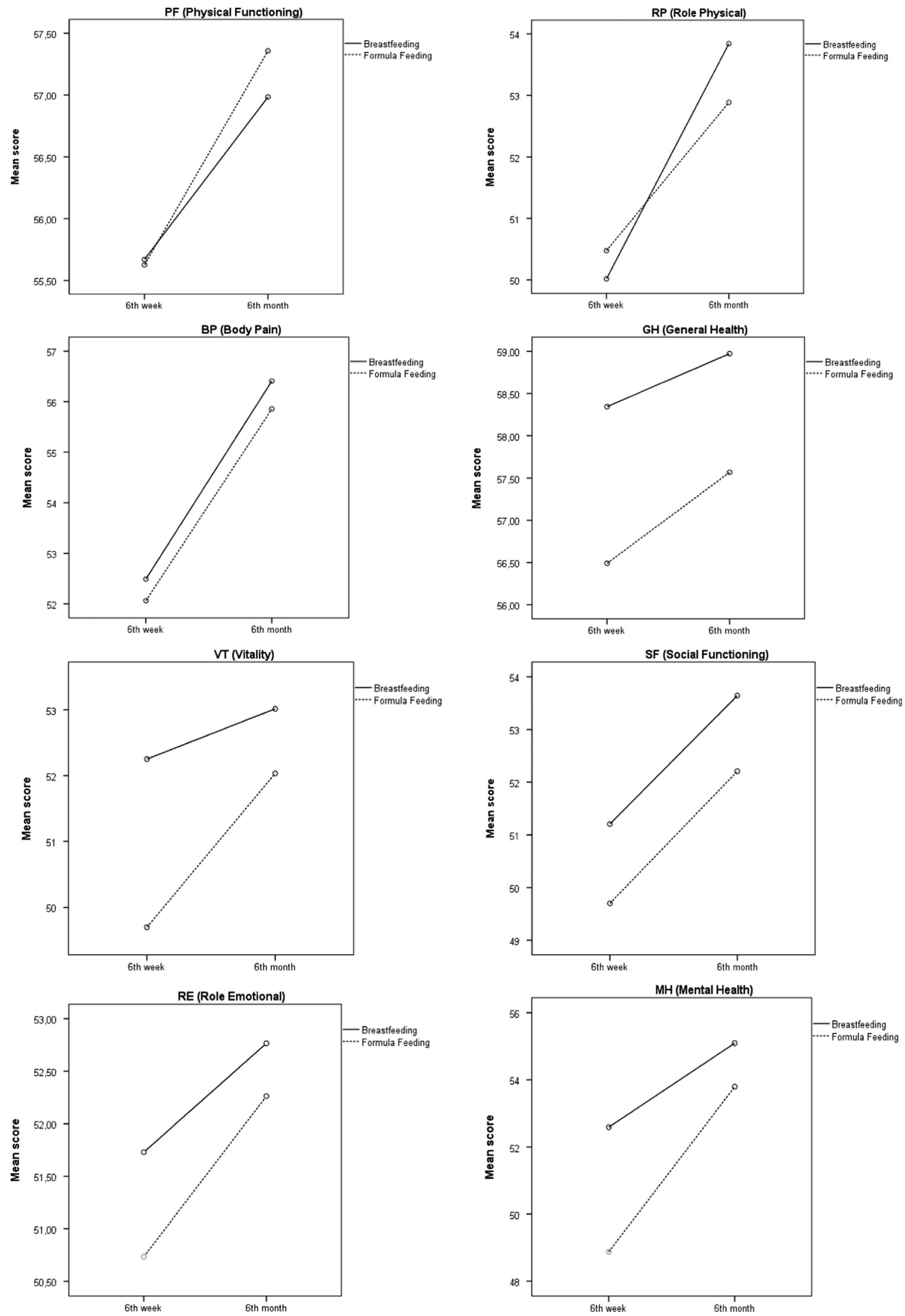

Fig. 1. SF-36 dimensions of women who maintained the same type of infant feeding between the sixth week and sixth month post partum. 

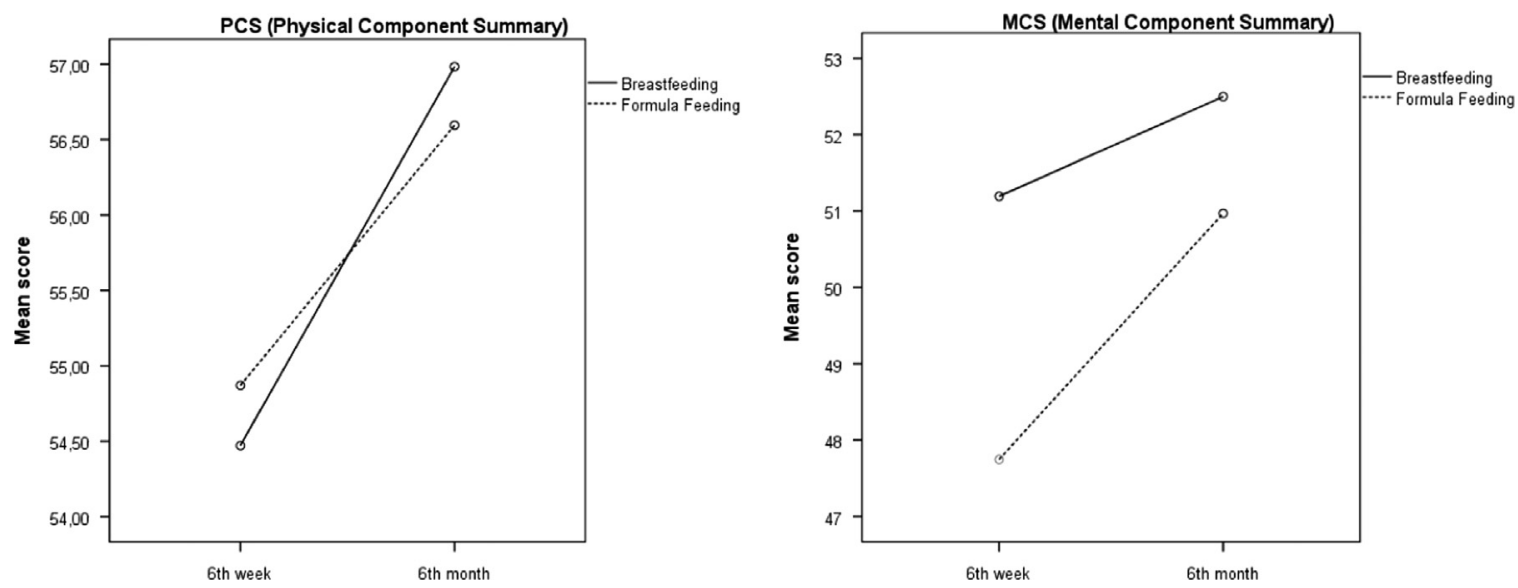

Fig. 2. SF-36 physical and mental components summary of women who maintained the same type of feeding between the sixth week and sixth month post partum.

Third, as we were unaware of the quality of life of the women during pregnancy, we cannot rule out the possibility that women with good mental health at the sixth week post partum already had good mental health before childbearing. Therefore, it would be appropriate to design new longitudinal studies that also measure the quality of life of women during pregnancy. Fourth, we did not collect data on maternal sleep or whether the mothers slept with their children at night. These factors could affect the type of infant feeding and maternal quality of life (Kendall-Tackett et al., 2011). Fifth, we did not collect information about whether women expressed breast milk or not. Therefore, it might be interesting that future studies include this aspect in data collection.

In conclusion, and after controlling for adjustment variables, we found no statistically significant differences in quality of life at six weeks post partum between women who breast fed and those who formula fed. Regardless of the type of infant feeding, mental health was found to be better at the sixth week post partum in women who reported that their children ate well and slept well and who attended the emergency hospital service less often because of concern over their baby's health. These findings were characteristic of women who breast fed their babies. No statistically significant differences in quality of life were found between the groups at six months post partum. Physical and mental health improved in both groups between the sixth week and sixth month post partum.

Therefore, we consider our findings to be of interest because they add to the scant scientific evidence available on the relationship between type of infant feeding and quality of life. We observed that breast feeding was indirectly and positively associated with short-term maternal quality of life. Consequently, improved quality of life through the well-being of the child could help to promote breast feeding.

\section{Funding}

This research was supported by Carlos III Institute of Health (Ministry of Economy and Competitiveness) and financed by the European Regional Development Fund; Grant number: PI12/ 03031. The funders had no role in study design, data collection and analysis, decision to publish, or preparation the manuscript.

\section{Conflict of interest}

The authors declare that they have no competing interests.

\section{Acknowledgements}

We want to thanks to all the mothers who participated in this study. Also, we want to thank to José María Bellón Cano, who helped with the statistical analysis, and to Ana Belén Jiménez Muñoz, Mireia Cantero Caballero and Cristina Rodríguez Rieiro, who collaborated with the study design. We want to thanks to all the members who belong to the investigation group, too.

\section{References}

Alonso, J., Prieto, L., Antó, J.M., 1995. [The Spanish version of the SF-36 Health Survey (the SF-36 health questionnaire): an instrument for measuring clinical results]. Med. Clin. (Barc), 104; , pp. 771-776.

Bai, D., Fong, D., Tarrant, M., 2015. Factors associated with breastfeeding duration and excusivity in mothers returning to paid employment postpartum. Mater Child Health J. 19, 990-999.

Baztan, I., Ortega, I., Armendariz, Y., Barace, E, 2009. Evolucion de la lactancia materna en la población que atiende el centro de salud de Mendillori [Evolution of breast feeding in the population attending the Mendillorri Health Centre]. An Sist Navar 32, 23-29.

Boettcher, J.P., Chezem, J.C., Roepke, J., Whitaker, T.A., 1999. Interaction of factors related to lactation duration. J. Perinat. Educ. 8, 11-19. http://dx.doi.org/ $10.1624 / 105812499 X 87079$.

Castro-García, C., Pazos-Morán, M., 2007. Permisos de maternidad, paternidad y parentales en España: algunos elementos para el análisis de la situación actual [Maternity, paternity and parental leave in Spain: some elements for the analysis of the current situation]. In: Morán, M.P. (Ed.), Economía e igualdad de género: retos de la hacienda pública en el siglo XXI. Instituto de Estudios Fiscales, Madrid.

Chen, T.L., Tai, C.J., Chu, Y.R., Han, K.C., Lin, K.C., Chien, L.Y., 2011. Cultural factors and social support related to breastfeeding among immigrant mothers in Taipei City, Taiwan. J. Hum. Lact. 27, 41-48. http://dx.doi.org/10.1177/ 0890334410376519.

Chen, Y.C., Chie, W.C., Kuo, S.C., Lin, Y.H., Lin, S.J., Chen, P.C., 2007. The association between infant feeding pattern and mother's quality of life in Taiwan. Qual. Life Res. 16, 1281-1288. http://dx.doi.org/10.1007/s11136-007-9233-1.

Chuang, C.H., Chang, P.J., Hsieh, W.S., et al., 2007. The combined effect of employment status and transcultural marriage on breast feeding: a population-based survey in Taiwan. Paediatr. Perinat. Epidemiol. 21, 319-329. http://dx.doi.org/ 10.1111/j.1365-3016.2007.00828.x.

Cohen Engler, A., Hadash, A., Shehadeh, N., Pillar, G., 2012. Breastfeeding may improve nocturnal sleep and reduce infantile colic: potential role of breast milk melatonin. Eur. J. Pediatr. 171, 729-732. http://dx.doi.org/10.1007/ s00431-011-1659-3.

Cox, J.L., Holden, J.M., Sagovsky, R., 1987. Detection of postnatal depression. Development of the 10-item Edinburgh Postnatal Depression Scale. Br. J. Psychiatry $150,782-786$.

Cubero, J., Valero, V., Sánchez, J., et al., 2005. The circadian rhythm of tryptophan in breast milk affects the rhythms of 6-sulfatoxymelatonin and sleep in newborn. Neuro Endocrinol. Lett. 26, 657-661.

de Tychey, C., Briançon, S., Lighezzolo, J., et al., 2008. Quality of life, postnatal depression and baby gender. J. Clin. Nurs. 17, 312-322. http://dx.doi.org/ 10.1111/j.1365-2702.2006.01911.x.

Domingo-Salvany, A., Bacigalupe, A., Carrasco, J.M., Espelt, A., Ferrando, J., Borrell, C., 2013. Proposals for social class classification based on the Spanish National Classification of Occupations 2011 using neo-Weberian and neo-Marxist 
approaches. Gac. Sanit. 27, 263-272. http://dx.doi.org/10.1016/j. gaceta. 2012.12.009.

Estévez González, M., Martell Cebrián, D., Medina Santana, R., García Villanueva, E., Saavedra Santana, P., 2002. Factors associated with discontinuance of breastfeeding. An. Esp. Pediatr. 56, 144-150.

EURO-PERISTAT, 2013. Project with SCPE and EUROCAT. European Perinatal Health Report. The Health and Care of Pregnant Women and Babies in Europe in 2010. Available $\langle$ www.europeristat.com〉.

Feldman, R., Eidelman, A.I., 2003. Direct and indirect effects of breast milk on the neurobehavioral and cognitive development of premature infants. Dev. Psychobiol. 43, 109-119. http://dx.doi.org/10.1002/dev.10126.

Flacking, R., Ewald, U., Nyqvist, K.H., Starrin, B., 2006. Trustful bonds: a key to "becoming a mother" and to reciprocal breastfeeding. Stories of mothers of very preterm infants at a neonatal unit. Soc. Sci. Med. 62, 70-80. http://dx.doi.org/ 10.1016/j.socscimed.2005.05.026.

Garcia-Esteve, L. Ascaso, C. Ojuel, J. Navarro, P. 2003. Validation of the Edinburg Postnatal Depression Scale (EPDS) in Spanish mothers. J. Affect. Disord. 75, $71-76$

Haas, J.S., Jackson, R.A., Fuentes-Afflick, E., et al., 2005. Changes in the health status of women during and after pregnancy. J. Gen. Intern. Med. 20, 45-51. http://dx. doi.org/10.1111/j.1525-1497.2004.40097.x.

Hegney, D., Fallon, T., O'Brien, M.L., 2008. Against all odds: a retrospective casecontrolled study of women who experienced extraordinary breastfeeding problems. J. Clin. Nurs. 17, 1182-1192. http://dx.doi.org/10.1111/ j.1365-2702.2008.02300.x.

Hernández, R., Fernández, C., Baptista, M.P., 2010. Metodología de la Investigación. In: Quinta Edición (Ed.), Metodología de la Investigación. Mc-Graw Hill, México, D.F.

Ibanez, G., Martin, N., Denantes, M., Saurel-Cubizolles, M.J., Ringa, V., Magnier, A.M., 2012. Prevalence of breastfeeding in industrialized countries. Rev. Epidemiol. Sante Publique 60, 305-320. http://dx.doi.org/10.1016/j.respe.2012.02.008.

INE, 2013a. Encuesta Nacional de Salud 2011-2012. Determinantes de salud (sobrepeso, consumo de fruta y verdura, tipo de lactancia, actividad física, cuidados en el entorno familiar. Retrieved from: 〈http://www.ine.es/ss/Sate lite? $\mathrm{L}=$ es_ES\&C = INESeccion

$C \& c i d=1259926457058 \& p=1254735110672 \&$ pagename $=$ ProductosYServicio s\%2FPYSLayout>.

INE, 2013b. Indicadores de fecundidad. Retrieved from: 〈http://www.ine.es/jaxiT3/ Datos.htm?t=1579>.

Isabella, P.H., Isabella, R.A., 1994. Correlates of successful breastfeeding: a study of social and personal factors. J. Hum. Lact. 10, 257-264.

Jansen, A.J., Duvekot, J.J., Hop, W.C., et al., 2007. New insights into fatigue and health-related quality of life after delivery. Acta Obstet. Gynecol. Scand. 86, 579-584. http://dx.doi.org/10.1080/00016340701275424.

Johnston, M.L., Esposito, N., 2007. Barriers and facilitators for breastfeeding among working women in the United States. J. Obstet. Gynecol. Neonatal Nurs. 36, 9-20. http://dx.doi.org/10.1111/j.1552-6909.2006.00109.x.

Kelly, Y.J., Watt, R.G., Nazroo, J.Y., 2006. Racial/ethnic differences in breastfeeding initiation and continuation in the United kingdom and comparison with findings in the United States. Pediatrics 118, e1428-e1435. http://dx.doi.org 10.1542/peds.2006-0714.

Kendall-Tackett, K., Cong, Z., Hale, T.W., 2011. The effect of feeding method on sleep duration, maternal wellbeing, and postpartum depression. Clin. Lact. 2 (2), 22-26.

Kim, S.H., 2010. Factors affecting mother's adaptation to breastfeeding. J. Korean Acad. Nurs. 40, 225-235. http://dx.doi.org/10.4040/jkan.2010.40.2.225.

Kramer, M.S., Kakuma, R., 2004. The optimal aduration of exclusive breastfeeding: systematic review. Adv. Exp. Med. Biol. 554, 63-77.

Ladomenou, F., Moschandreas, J., Kafatos, A., Tselentis, Y., Galanakis, E., 2010. Protective effect of exclusive breastfeeding against infections during infancy: prospective study. Arch. Dis. Child. 95, 1004-1008. http://dx.doi.org/10.1136/ adc.2009.169912.

Manrique de Lara, D., Miraval, Z., Córdova, R., De la Mata, R., Maque, A., 2007. Influencia del acompañamiento de un familiar durante el trabajo de parto. Centro de Salud de Aparicio Pomares Huánuco, [Influence of support of family during labor. Health Center Aparicio Pomares Huánuco] 2004-2005. Inv. Valdizana 1, 6-9.

Ministerio de Sanidad, S. S. e. I., 2012. Informe anual del Sistema Nacional de Salud 2012. vol. 2015. pp. 191. Retrieved from: 〈http://www.msssi.gob.es/estadEstu dios/estadisticas/sisInfSanSNS/tablasEstadisticas/infsns2012.pdf).

Mogos, M.F. August, E.M. Salinas-Miranda, A.A., Sultan, D.H., Salihu, H.M. 2013. A systematic review of quality of life measures in pregnant and postpartum mothers. Appl. Res. Qual. Life 8, 219-250.

Mortazavi, F., Mousavi, S.A., Chaman, R., 2014. Does maternal quality of life influence breastfeeding difficulties? Iran. J. Pediatr. 24, 452-453.

Mortazavi, F., Mousavi, S.A., Chaman, R., Khosravi, A., 2014a. Do maternal quality of life and breastfeeding difficulties influence the continuation of exclusive breastfeeding? Int. J. Pediatr. 2014, 156049. http://dx.doi.org/10.1155/2014/ 156049.

Mortazavi, F., Mousavi, S.A., Chaman, R., Khosravi, A., 2014b. Maternal quality of life during the transition to motherhood. Iran. Red Crescent Med. J. 16, e8443. http: //dx.doi.org/10.5812/ircmj.8443.

Otchet, F., Carey, M.S., Adam, L., 1999. General health and psychological symptom status in pregnancy and the puerperium: what is normal? Obstet. Gynecol. 94, 935-941.

Ramírez, H., Rodríguez, I., 2014. Beneficios del acompañamiento a la mujer por parte de su pareja durante el embarazo, el parto y el puerperio en relación con el vínculo paternofilial. Revisión bibliográfica [Benefits of the support to the woman by her partner during pregnancy, childbirth and the post partum period in relation to the parent-child bond. Literature review]. Matronas Profesión 15, 1-6.

Rao, M.R., Hediger, M.L., Levine, RJ., Naficy, A.B., Vik, T. 2002. Effect of breastfeeding on cognitive development of infants born small for gestational age. Acta Paediatr. 91, 267-274.

Reynolds, A., 2001. Breastfeeding and brain development. Pediatr. Clin. N. Am. 48, 159-171.

Schmied, V., Barclay, L., 1999. Connection and pleasure, disruption and distress: women's experience of breastfeeding. J. Hum. Lact. 15, 325-334.

Schmied, V., Lupton, D., 2001. Blurring the boundaries: breastfeeding and maternal subjectivity. Sociol. Health Illn. 23, 234-250.

Schwartzmann, L., 2003. Calidad de vida relacionada con la salud: aspectos conceptuales [Health-related quality of life: Conceptual aspects]. Cienc Enferm 9, $9-21$.

Skafida, V., 2012. Juggling work and motherhood: the impact of employment and maternity leave on breastfeeding duration: a survival analysis on Growing Up in Scotland data. Matern. Child Health J. 16, 519-527. http://dx.doi.org/10.1007/ s10995-011-0743-7.

Tarrant, M., Kwok, M.K., Lam, T.H., Leung, G.M., Schooling, C.M., 2010. Breastfeeding and childhood hospitalizations for infections. Epidemiology 21, 847-854. http://dx.doi.org/10.1097/EDE.0b013e3181f55803.

Thulier, D., Mercer, J., 2009. Variables associated with breastfeeding duration. J. Obstet. Gynecol. Neonatal Nurs. 38, 259-268. http://dx.doi.org/10.1111/ j.1552-6909.2009.01021.x

Torkan, B., Parsay, S., Lamyian, M., Kazemnejad, A., Montazeri, A., 2009. Postnatal quality of life in women after normal vaginal delivery and caesarean section. BMC Pregnancy Childbirth 9, 4. http://dx.doi.org/10.1186/1471-2393-9-4.

Vilagut, G., Ferrer, M., Rajmil, L., et al., 2005. The Spanish version of the Short Form 36 Health Survey: a decade of experience and new developments. Gac. Sanit. $19,135-150$

Ware, J., Snow, K., Kosinski, M., Gandek, B., 1993. SF-36 Health Survey: Manual and Interpretation Guide. New England Medical Center, Boston.

WHO, 2008. Indicators for assessing infants and young child feeding practices. Part 1. Definitions. Washington, DC.

WHO \& UNICEF, 2009. Baby-Friendly Hospital Initiative. Revised, Updated and Expanded for Integrated Care.

WHO, 2003. Global Strategy for Infant and Young Child Feeding. Albany, NY, USA.

Zubaran, C., Foresti, K., 2011. The correlation between breastfeeding and maternal quality of life in southern Brazil. Breastfeed Med. 6, 25-30. http://dx.doi.org/ 10.1089/bfm.2010.0017. 